\title{
Pharmacological activity of Salvia lavandulifolia and chemical components of its essential oil. A review
}

\author{
María Porres-Martínez, $\mathbf{M}^{\mathrm{a}}$ Emilia Carretero Accame \& \\ Ma Pilar Gómez-Serranillos (*)
}

\begin{abstract}
Porres-Martínez, M., Carretero M.E. \& Gómez-Serranillos, M.P. Pharmacological activity of Salvia lavandulifolia Vahl. and chemical components of its essential oil. Lazaroa 34: 237-254 (2013).

Salvia lavandulifolia Vahl. is a plant from the Iberian Peninsula whose phytochemical evaluation indicated the presence of flavonoids, triterpenoids, diterpenoids and monoterpenes. It has an essential oil rich in various bioactive compounds (like 1,8-cineole or $\alpha$-pinene). It has been traditionally used for its spasmolytic, antiseptic, analgesic, sedative and anesthesic activities. Pharmacological studies of the plant have demonstrated its reputation as aromatic plant to enhance memory and anti-dementia drug by the inhibition of cholinesterase enzyme. The species also possesses a wide range of pharmacological uses including: antioxidant, anti-inflammatory, estrogenic and central nervous system depressant properties, relevant to the treatment of Alzheimer's disease. The present review summarizes the information concerning the taxonomy ecological and biogeographical features, ethnopharmacology, phytochemistry, pharmacological activities and toxicity of the Salvia lavandulifolia because these findings suggest the need for further research on this species.
\end{abstract}

Keywords: Salvia lavandulifolia Vahl, botanic, chemical composition, essential oil, traditional uses, pharmacological activities.

Resumen: Porres-Martínez, M., Carretero M.E. \& Gómez-Serranillos, M.P. Actividad farmacológica de Salvia lavandulifolia Valh y los componentes químicos de su aceite esencial. Lazaroa 34: 237-254 (2013).

Salvia lavandulifolia Vahl. es un taxon Ibérico cuya evaluación fitoquímica indica la presencia de flavonoides, triterpenos, diterpenos y monoterpenos. Su aceite esencial es rico en varios compuestos bioactivos (como 1,8-cineol o $\alpha$-pineno). Esta especie se ha utilizado tradicionalmente para sus actividad espasmolítica, antiséptica, analgésica, sedante y anestésica. Los estudios farmacológicos sobre la misma han demostrado su reputación como planta aromática para mejorar la memoria y contra la demencia por la inhibición de la enzima colinesterasa. La especie también posee un amplia actividad farmacológica, incluyendo: antioxidante, antiinflamatoria, estrogénica y depresora del sistema nervioso central, propiedades relevantes para el tratamiento de la enfermedad Alzheimer. Esta revisión resume la información taxonómica, biogeográfica, ecológica y también la referente a la etnofarmacología, fitoquímica, actividades farmacológicas y toxicidad de la planta Salvia lavandulifolia, y sugieren la necesidad de investigaciones adicionales sobre esta planta.

Palabras clave: Salvia lavandulifolia Vahl, botánica, composición química, aceite esencial, usos tradicionales, actividades farmacológicas.

\section{INTRODUCTION}

The genus Salvia of Lamiaceae is widely distributed and it is used extensively as ethnomedicinal plant. The Lamiaceae family is compound by 200 genus and 3000 species (ToPCU, 2006). Salvia L. (sage), belongs to Mentheae Tribe, is the largest and more diverse genus of this family and it is represented by 900 recognized species, native of Mediterranean. Nevertheless, widespread almost all around the world, abundantly located in three areas: through Europe around the Mediterranean, to South-East Asia and more than half of species across Central and South America

* Department of Pharmacology. Faculty of Pharmacy. Universidad Complutense de Madrid. E-28040 Madrid, Spain. E-mail: m.porres@farm.ucm.es,meca@farm.ucm.es,pserra@farm.ucm.es 
(Gali-Muhtasib \& al., 2000; Walker \& al., 2004).

The genus name Salvia is derived from Latin word 'salvare' meaning 'to heal or to be safe and unharmed' referring to the medicinal properties of some of the species (Blumenthal \& al., 2000). For centuries Salvia species are used as folk medicine for its curative properties. Sage has a historical reputation in Greek, Egyptian, indigenous American Indian, Roman ceremonies as a sacred herb and especially by traditional Chinese medicines, for promotion of health and treatment of illness, and as an herb for longevity. A proverb assures that "How can man die that has sage in the garden?" (FonT-QUER, 1999). Pliny the Elder (23-79 AD) reported the properties of sage as enhancer of memory functions and the importance of this plant in traditional medicine (RAMOS \& al., 2010). Whereas the Greek physician Dioscorides reported sage stop bleeding wounds and sores besides clean ulcers after aqueous decoction of the plant. Besides, juice warm water is used for hoarseness and cough (Blumenthal \& al., 2000). Several species of Salvia genus present therapeutic activity due to their essential oils. Salvia was used in folk medicine all around the world from epilepsy, treat colds, bronchitis, tuberculosis, hemorrhage, and menstrual disorders (DwECK, 2000; TOPCU, 2006; TILDESLEY \& $a l ., 2005)$ and as antiseptic, astringent, depurative, digestive, expectorant, febrifuge and tonic, and also externally as insecticide, skin and month or throat infections (JIROVETZ \& al., 2007; GonZÁLEZ \& al., 2012). Moreover, species belonging to this genus are also known for other biological activities, such as anti-inflammatory, antidiabetic, antimicrobial, antitumor or anxiolytic activities (LOIZZO \& al., 2009; KELEN \& TEPE, 2008) or antispasmodic, antimalarial, anticancer or antifungal. Furthermore, it also preserves food due its antioxidant properties, as well as spice for its natural flavor (GUILLÉN \& IBARCOITIA, 1995; Topcu, 2006).

About $25 \%$ of modern drugs are originated from plants either directly or indirectly. Phytochemical and pharmacological researches carried out during last years confirm many traditional uses of Salvia genus in central nervous system di-

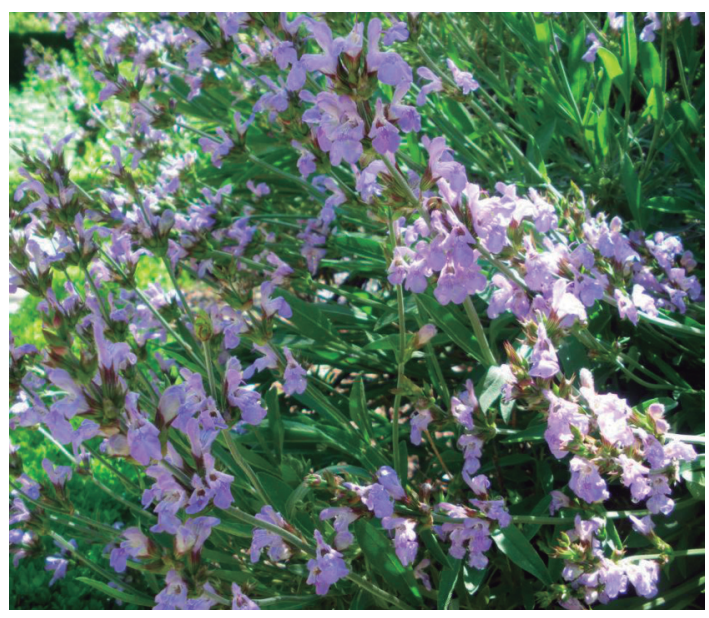

Figure 1. - Salvia lavandulifolia Vahl.

sorders (IMANSHAHIDI \& HosseINZADEH, 2006). It is necessary therapeutic agents for nervous system disorders with reduce toxicity and side effects and with safety and acceptability. Salvia lavandulifolia present no reported adverse effects from its long use as flavoring in food (PERRY \& al., 2001). Sage genus, including Salvia lavandulifolia (Figure 1), has been used by humans for more than two millennia in the treatment of different age related cognitive disorders associated with ageing to enhance cognitive function and attenuate cognitive decline (KENNEDY \& WightMAN, 2011). In addition beneficial effects on disorders of central nervous systems as cognitive disorders, depression and cerebral ischemia have been demonstrated (AKHONDZADEH \& al., 2003; Howes \& al., 2003). In recent controlled trials, administration of sage extracts, with known cholinergic characteristic improve behavioral and cognitive function in healthy young adults humans, and also improve memory and attention in healthy older volunteers by its anticholinesterase properties relevant to Alzheimer's disease therapy (WAKE \& al., 2000; SCHOLEY \& al., 2008; LOIZZO \& al., 2009). Cholinesterase inhibiting from botanical origin, used to the treatment of these diseases modifies the progress and symptoms of the diseases (ABASCAL \& YARNELL, 2004a; KENNEDY \& SCHOley, 2006; AdAMS \& al., 2007). In Alzheimer's disease the biological mechanism underlying dementia is: neuronal damage caused by 
oxidative stress and inflammatory reactions; disrupted cholinergic transmission; and beta-amyloid formation or toxicity (PERRY \& al., 1999). Most of current treatments increase the availability of neurotransmitter acetylcholine through the inhibition of cholinesterase enzymes (KENNEDY $\&$ SCHOLEY, 2006).

Aromatic plants are important as food-flavouring agent and spice, in cosmetic or perfumes but also for their pharmaceutical and therapeutical properties with less adverse effects than synthetic drugs. The use of essential oils for healing purposes has been known in folk medicine since ancient times, however the pharmacology studies on whole essential oil and their constituents are very little (PERRY \& PERRY, 2006; Franz, 2010). There are several studies on analyses of quantitative and qualitative changes in essential oils of sage, and genetic and morphological variations are observed according to their geographical origin and growth stage (AMIRI, 2007). The greatest use of essential oil is in food as flavorings, perfumes as fragrances, pharmaceuticals (BURT, 2004) and as ornamental (CLEBSCH, 2003; PEURAT \& al., 2012). S. lavandulifolia essential oil inhibits the enzyme acethylcholinesterase; and present antioxidant, anti-inflammatory and estrogenic activity. Therefore, the plant has notable reputation for its potentially relevant activities in brain function as cognition enhancing, beneficial effects on behavioral, for treatment of depression, memory disorder, and preventive and symptomatic treatment of age-related memory decline (PERRY \& al., 1998).

\section{TAXONOMICAL, GEOGRAPHICAL AND ECOLOGICAL FEATURES}

Salvia lavandulifolia Valh. is native from the Iberian Peninsula (Figura 2), which is the reason of its common name "Spanish sage". It was considered as an medicinal species from ancient times (CAÑIGUERAL \& al., 1998). The geographical distribution is similar to actual one however it is thought that the species most probably arrive to Iberian Peninsula through North of Africa. Different factors such as historic, geographic, geolo- gic, and climatic could have influenced on its present-day distribution. The isolation of populations makes possible the microevolution of the species (RosuA \& BLANCA, 1990). This species is widely spread over the Mediterranean area, mainly in East of Spain (especially in Andalucia, Murcia and Castilla), just extending into western Mediterranean: South East France, North West Africa (Morocco and Algeria) (JoRDAN \& al., 2009; SÁEZ, 2010). Salvia lavandulifolia is very adapted to the semiarid Mediterranean climate, growing in rocky soil in sandy-calcareous mountains. This plant can be found in altitudes from 350 to 2000 $\mathrm{m}$ above the sea level. The species grows on types of soil, preferably on slightly deep and basic soils, on limestone substrate, loamy or gypsum (MARCOS \& al., 1988; SÁEZ, 2010). While it commonly grows wild, the cultivated plots are also shown. Salvia grows optimally in full sun and needs welldrained soil (CRESPO \& al., 1986; PAGES \& al., 1992).

Salvia lavandulifolia Vahl. is characterized by a small sub-shrub or herb up to $17-100 \mathrm{~cm}$, stems branched, erect and pubescent, tector hairs sometimes glandular. The leaves grow opposite each other on the stem and appear to grow in bunches. They are green or gray-white, simple and petiolate with hair protectors, limbo from, elliptic to linear-lanceolate and petiole $5-54 \mathrm{~mm}$. The inflorescence, $5-71 \mathrm{~cm}$, simple or branched, with 2-8 flowers. Bracts are ovate, lanceolate, green or violet color. Flowers present pedicels and calyx of 8-14 mm, regular, tubular or campanulate,

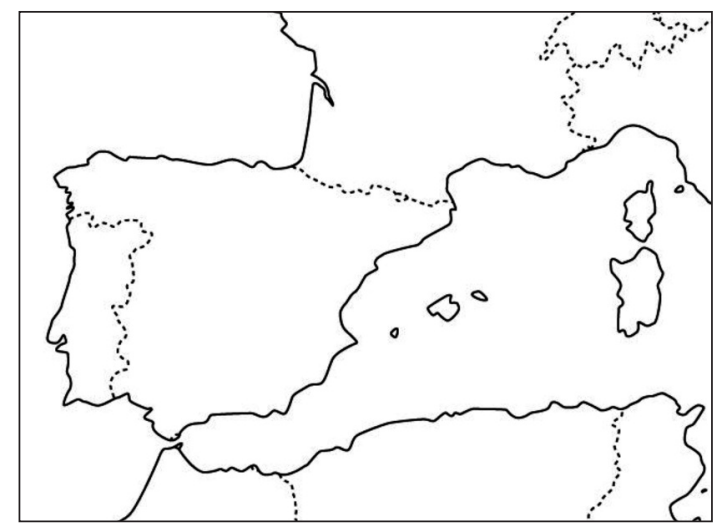

Figure 2. - Distribution of Salvia lavandulifolia in Western Mediterranean Basin. 
usually green or violet-purple, pubescent. Its corolla of $15-40 \mathrm{~mm}$ in size, pink, purple or blue violet, straight, laterally compressed. The blooming develops for about one month in late spring and early summer (Hedge, 1972; SÁEZ, 2010). The leaf presents seasonally dimorphic (PALACIOS \& al., 2008). The different subspecies of Salvia lavandulifolia has been studied in diverse geographical regions of Spain by different authors (VALDÉS-BERMEJO \& LÓPEZ, 1977; ROSUA \& BLANCA, 1985, 1988; FERNÁNDEZ-GoNZÁLEZ \& al., 1986; Figuerola, 1987; DONAIRE \& al., 1992; HERVÁsSERRANO \& al., 1997; Solanas \& CRESPO, 1998; SALHI \& al., 2010; LAZARO BELLO, 2011). Till date five different subspecies have been described: $S$. lavandulifolia subsp. lavandulifolia, S. lavandulifolia subsp. vellerea, S. lavandulifolia subsp. mariolensis, S. lavandulifolia subsp. blancoana and S. lavandulifolia subsp. oxyodon (SÁEz, 2010).

\section{ETHNOPHARMACOLOGY}

Salvia species have been widely used since the Middle Ages. The English herbalist John Gerard (1545-1607) wrote about sage in 1597, "It is singularly good for the head and brain and quickened the nerves and memory." About 50 years later, English physician Nicholas Culpeper (16161654) wrote in 1652, "It also heals the memory, warming and quickening the senses." John Hill (1714-1775), in 1756, said "Sage will retard that rapid progress of decay that treads upon our heels so fast in later years of life, will preserve faculties and memory more valuable to the rational mind than life itself". Salvia tea is described by Grieve in 1980 as a "highly serviceable stimulant tonic in debility of the nervous system" (HougTON \& al., 2004; PERRY \& al., 2000b).

Salvia has been considered as a 'panacea' throughout the world. The traditional uses recorded for this plant, are numerous and mainly medicinal. This aromatic species is frequently used as folk remedies to treat some diseases and several of these pharmacological effects have been demonstrated in controlled laboratory studies (CRESPO \& al., 1986). It is a common food supplement (THACKERAY \& al., 2010). But also play an important role in preservation of foods due organoleptic properties of terpenes, sesquiterpenes and oxygenated derivates (GUILLÉN \& MANZANOS, 1999) and cosmetic industry for its fragrance (cosmetic and perfumes). It is used in perfumes and for flavoring because it is not irritant, sensitizing to human skin and non-phototoxic (DWECK, 2000). Since ancient Greek, sage has a history as a cognition enhancer and treatment of memory decline. Several chemical and pharmacological studies of this aromatic plant are described in the literature, as sources of natural antioxidant with health benefits. Indications have traditionally included beneficial effects on central nervous system, mainly in mood and memory enhancement age-related because of their anticholinesterase activity, depression or epilepsy might hence be due to a combination of actions (PERRY \& al., 2000b; TILDESLEY \& al., 2003)

$S$. lavandulifolia has been used in traditional medicine for its therapeutic properties as spasmolytic, antiseptic (bactericidal, virucidal and fungicidal), analgesic, sedative, anti-inflammatory and locally anesthetic remedies. This herbal medicine has been utilized for their psychoactive and psychotropic properties. The leaves of S. lavandulifolia are traditionally used as a choleretic, astringent, cicatrizing and antiseptic drug (CAÑIGUERAL \& al., 1989; ZRIRA \& al., 2004), and also antiperspirant effect for menopause symptoms. Aqueous extract present hypoglycemic activity (ZARZUELO \& al., 1991), and is used as folk remedies to treat diabetic hyperglycemia. The essential oil of the plant is rich of compounds not only with antimicrobial and antiviral activities but also with antioxidant properties. Others notable ailments for which this plant has been used includes depression (PERRY \& al., 2000b).

\section{PHYTOCHEMISTRY}

Besides its morphological complexity, $S$. lavandulifolia shows a well-known variability in its chemical constituents, many of them have been identified, and also present many physical characteristics. The main secondary metabolites are flavonoids and terpenoids. JOHNSTON \& BEART 
(2004) suggest that flavonoids have the potential to manage several psychiatric and neurological disorders. Flavonoids, triterpenoids and monoterpenes (present in volatile compounds) are usual components of aerial parts found in flowers and leaves, whereas diterpenoids are the main compounds of roots (ESCUDERO \& al., 1983; ULUBELEN \& al., 2000; BARICEVIC \& BARTOL, 2000; TOPCU, 2006). The herb presents phenolic monoterpenoid, flavones and the phenolic rosmarinic acid. Salvia is also a rich source of polyphenols (ZARZUELO \& al., 1995; CAÑIGUERAL \& al., 1989; Lu \& FoO, 2002).

\section{ESSENTIAL OIL}

At room temperature, much of them are a chemically complex mixture of aromatic oily liquids, insoluble in water and soluble in organic solvents, whose constituents of secondary metabolism are biosynthesized from aromatic plants (e.g. flowers, leaves, herbs, fruits, roots or wood). Essential oil of plant is a mixture of great number of terpenic components synthesizes in the cells of the leaf trichomes and stored in the glandular hairs of aerial parts (GIANNOULI \& al., 2000). Monoterpenes incorporate 2 isoprene units (C10) and are the most representative molecules of essential oils (WANG \& al., 2010). Volatile oils of Salvia usually present more than 100 individual components at different concentrations. Several authors have published the phytochemical analysis showing the presence of many compounds on the essential oil composition of this species (LAWRENCE \& al., 1970; JORDAN \& al., 2009; GUILLEN \& al., 1999; Cardile \& al., 2009; Herraiz \& al., 2010). Most of these studies concern the variations of a few major essential oil constituents, without study the high number of minor compounds. The essential oil percentage composition gives an important characteristic to classify each plant (SANTOS-Gomes \& FERnANDES-FERREIRA, 2001).

Their components are volatile monoterpenoids whose main common active compounds which define the chemotype of the essential oil include 1,8-cineole (Guillen \& IbARGoItia, 1995; SAVELEV \& al., 2003; PERRY \& al., 2000a) and cam- phor. The chromatographic profile are: 1,8-cineole or eucalyptol (11-25\%), camphor (11-36\%), $\alpha$-pinene $(4-11 \%)$, sabinene $(0.1-3 \%)$, limonene (2$5 \%)$, linalool $(0,5-9 \%)$, borneol $(1-8 \%)$, linalil acetate $(<5 \%)$ and terpin-1-en-4-ol $(<2 \%)$. $\beta$-caryophyllene is a non-steroidal anti-inflamatory sesquiterpene with gastric cytoprotection activity (TAMBE \& al., 1996). The Chromatographic profile according to the standard UNE 84310:2001 (AENOR, 2001) for Salvia lavandulifolia essential oil is shown in Table 1.

Table 1

Chromatographic profile for Salvia lavandulifolia essential oil (AENOR, 2001)

\begin{tabular}{lcc}
\hline Components & Min. (\%) & Max. (\%) \\
\hline$\alpha$-pinene & 4 & 11 \\
sabinene & 0.1 & 3 \\
limonene & 2 & 5 \\
1,8 -cineole & 11 & 30 \\
linalool & 0.3 & 4 \\
camphor & 15 & 36 \\
borneol & 1 & 5 \\
terpinen-4-ol & & $<2$ \\
linalil acetate & 0.1 & 5 \\
$\alpha$-terpenil acetate & 0.5 & 9 \\
sabinil acetate & 0.5 & 9 \\
\hline
\end{tabular}

The gas chromatography analyses allowed the identification and relative quantification of components of this sage species after the isolation of essential oil by hydro-distillation usually. This essential oil is obtained from the dried parts of the plant using a Clevenger apparatus for $4 \mathrm{~h}$ (ANON., 2004). After the extraction, the oil is colorless to slightly yellow with fine fragrance oil, camphoraceous and cineole-like (VERNIN \& MetZGER, 1986). Volatile constituents of the essential oil probably cross the blood-brain barrier by their lipophilicity and small molecular size (SAVELEV \& al., 2004).

\section{PHARMACOLOGICAL ACTIVITIES}

Plenty of investigations indicated that Salvia genus has been popular in phytochemical and ethnobotanical research, revealing important phar- 
macological properties, in vitro as well as in vivo, with fewer side effects. There are several studies of S. lavandulifolia extracts and constituents that investigate their traditional, central nervous system related use. Its antioxidant, anticholinesterase, anti-inflammatory, oestrogenic and central nervous system depressant effects are relevant to the treatment of some neurodegenerative problems as Alzheimer's disease (MANTLE \& al., 2000; Houghton \& Howes, 2005; Kennedy, 2009). Several studies relate with neurodegenerative problems are explain in Table 2 . The activity properties on central nervous system (CNS) of this plant are attributable to the presence of potentially active secondary metabolites constituents (Panagiotopoulos \& al., 2000). These chemicals, that may improve brain function, are synthesized to increase the suitability of the plant to survive to pathogens or environment and potential effectiveness as nootropics (KENNEDY \& Wightman, 2011). Terpenoids present biological activities, some of them very relevant as neuroprotective, important for the treatment of several diseases (CHANG \& al., 2007) and in protection against pathological or stress conditions (BAKKALI \& al., 2008). The main disadvantage of natural products is the small quantity that can be extracted from each plant. Numerous literatures have recently reported the chemical composition, biological properties, and possible applications of essential oils as a source of pharmaceutical natural products. Synergistic or antagonistic interactions among the components increase the potency, and also the activity of compound in minor percentage of essential oil mixture has to be considered (BURT, 2004).

\section{ANTIOXIDANT ACTIVITY}

Many diseases of the nervous system involve free radical damage due to an excess of reactive oxygen species. The cellular damage to lipid, protein and DNA is associated with a number of diseases, as neurodegenerative disorders. Antioxidant activity limiting free radical damage of sage oil was correlated with diterpenes and oxygenated sesquiterpenes concentration (PAPAGEORGIOU \& al., 2008). The activity in enzyme-dependent and enzyme independent systems of lipid peroxidation (ZUPKO \& al., 2001); carvacrol, luteolin and rosmarinic acid with potent scavenging activity in herb, and 1.8-cineole, linalool, $\alpha$ and $\beta$-pinene in essential oil by inhibition of bovine brain liposome peroxidation by the ARUOMA \& al. method (1996). Thujone and geraniol present lower effect (PERRY \& al., 2001) as well as eugenol and thymol, and other methylisopropylphenols (GUILLEN \& MANZANOS, 1999). The potential antioxidant activity depends on concentration and systems used (PERRY \& al., 2003). Camphor instead presents pro-oxidant properties in a liposome peroxidation preparation, but this activity may not have effect in the whole essential oil (PERRY \& $a l ., 2001)$ and its association with neurotoxicity (convulsive) at high doses. Salvia lavandulifolia water extracts protects DNA against $\mathrm{H}_{2} \mathrm{O}_{2}$ induced damage in HeLa cells by acting on reactive species or by stimulating endogenous defense systems, only $21 \%$ due its low levels of phenolics compounds (RAMOS \& al., 2010).

\section{ANTI-INFLAMMATORY ACTIVITY}

Inflammation is associated with effects in disorders of nervous system. There are many studies regarding the anti-inflammatory activity of plants is produced by phenolics and flavonoids as carvacrol, the flavones genkwarin and luteolin and the 6-hydroxy flavones cirsimaritin and salvigenin and polyphenolics as rosmarinic acid, and the monoterpenoid present in the essential oil: $\alpha$ pinene (that inhibit the enzyme cycloxygenase and weak selectivity for eicosanoid, leukotriene B4 [LTB4] that was measured by radio immunoassay) and geraniol show weak selectivity for the thromboxane B2 [TXB2]. Both of them present significant inhibition of synthesis of pro-inflamatory eicosanoid in rat leucocytes stimulated by calcium-ionophore method (PERRY \& al., 2001; PERRY \& al., 2003).

\section{OESTROGENIC ACTIVITY}

Oestrogenic activity has been suggested to play a role in the prevention or deletion of neurodegeneration perhaps by protection against neuronal loss. 


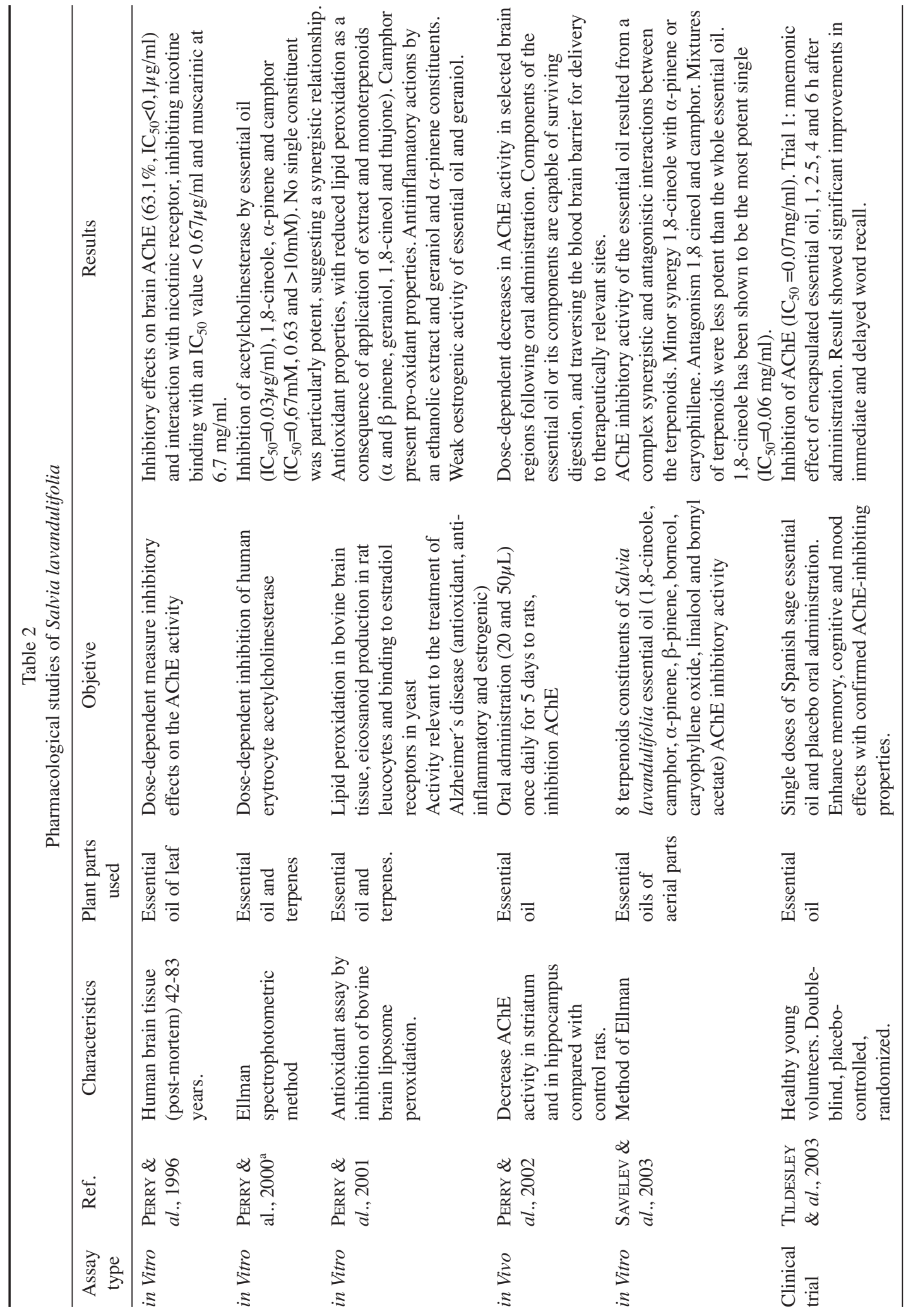



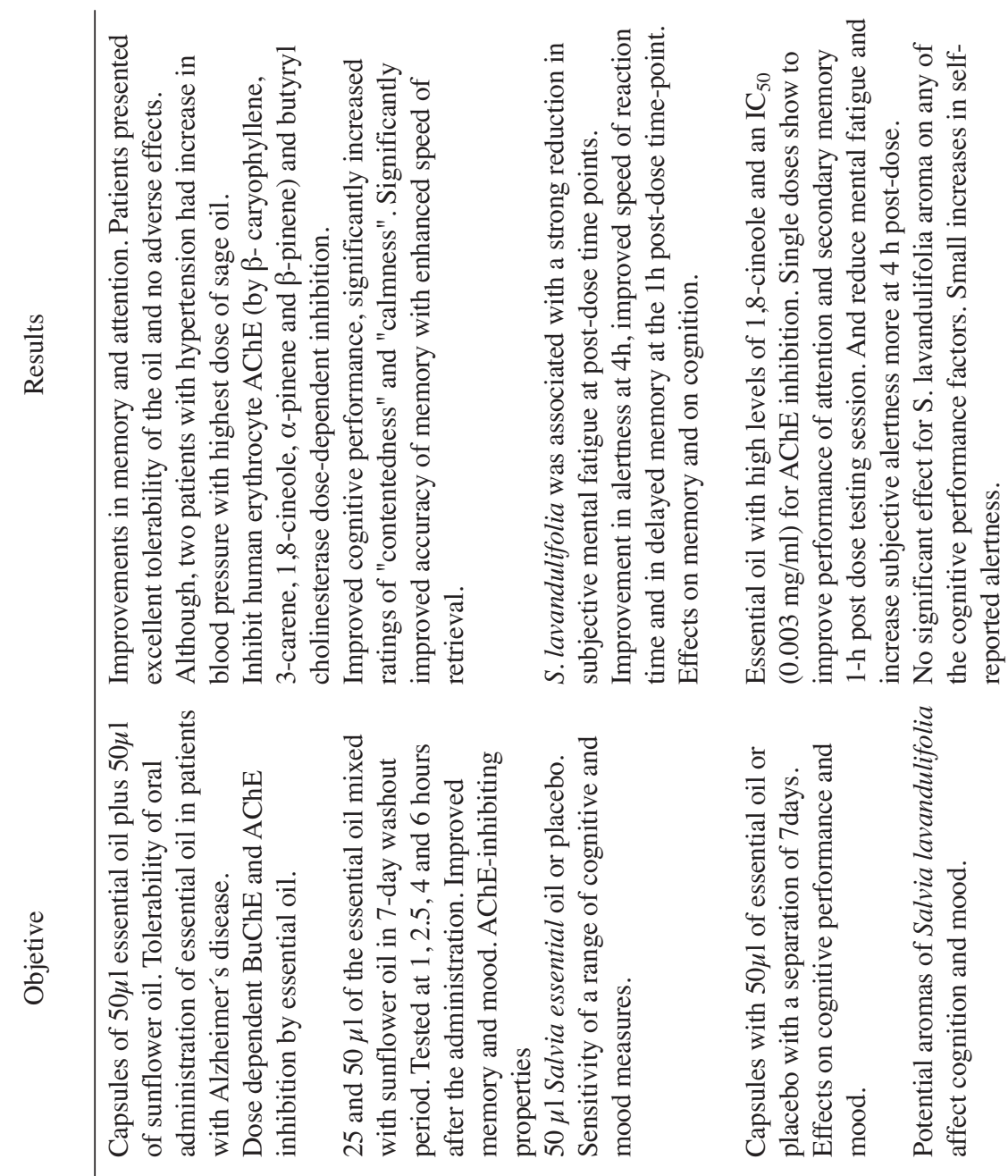

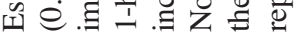
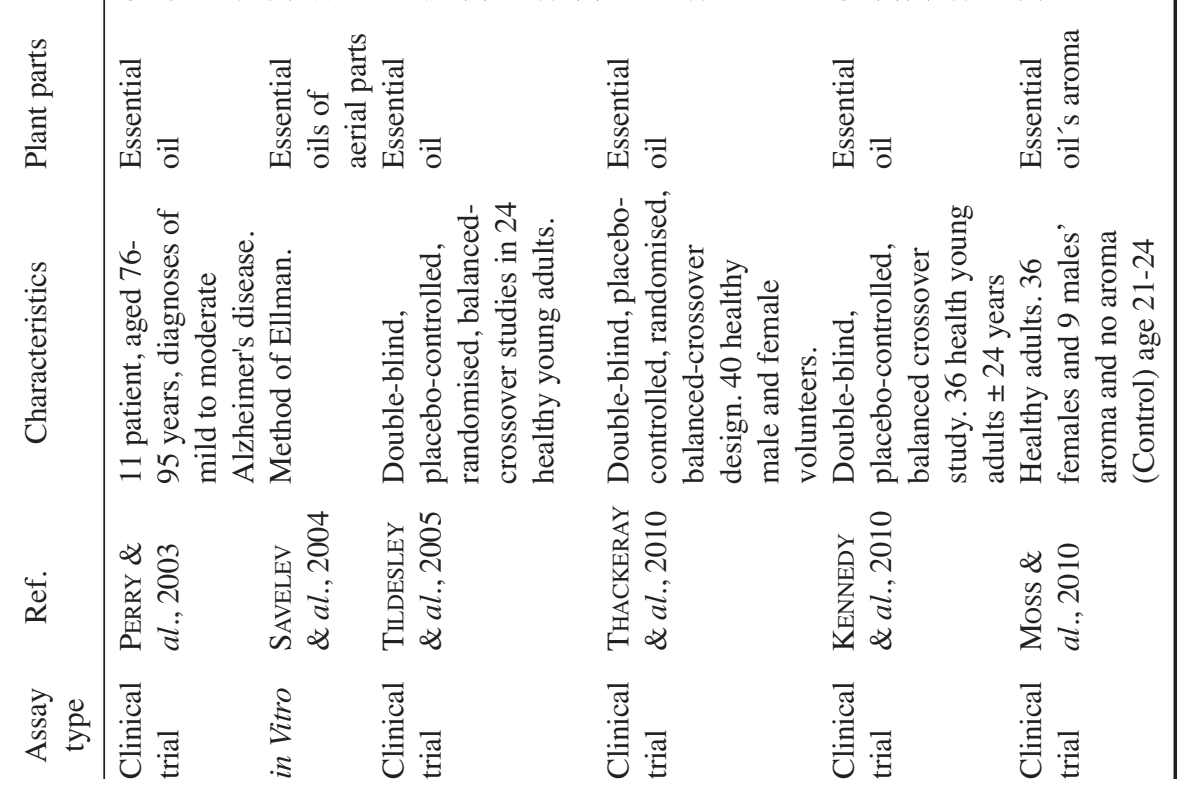
Oestrogenic activity and no dose-dependent activity were demonstrated in essential oil of S. lavandulifolia, maybe for the volatility of its components (PERRY \& al., 2001). The essential oil and their monoterpenoid constituent geraniol, with hydroxyl group, present a weak oestrogenic activity by induction of $\beta$-galactosidase activity in yeast cells ( $\mathrm{Sac}$ charomyces cerevisiae) (PERRY \& al., 2003).

\section{CHOLINESTERASE INHIBITORY ACTIVITY}

Increasing levels of the neurotransmitter acethylcholine and their synaptic availability are due to a delay in the catabolism of acethylcholine (ACh) (Houghton \& al., 2006). Acetylcholine (ACh) transmitted electrical impulses, by nerve cells to another nerve cell or to muscles. The receptors sensitive to ACh usually are muscarinic or nicotinic. The enzymes acetylcholinesterase (AChE) hydrolyses the ACh and produces a loss of stimulatory activity. Inhibit the cholinesterase group of enzymes results in a prolongation of the activity of ACh. Colorimetric method developed by ELLMAN \& al., (1961) is widely used to detection of AChE inhibition (MIYAZAWA \& YAMAFUJI, 2005). This is very important in the treatment of diseases associated with low levels of Ach in the brain as in Alzheimer's disease by improving cognitive function (Houghton \& al., 2006). Sage has previously been shown to improve cognitive function and to inhibit cholinesterase. Acetylcholine has an important role in cognitive functions such as memory, learning and attention (TILDESLEY \& al., 2003) and for problems associated with aging such as memory loss (PERRY \& al., 1999). Several studies show that Salvia species present properties relevant to the attenuation of cognitive declination by the inhibition of the brain enzymes in vitro butyrylcholinesterase and acethylcholinesterase (PERRY \& al., 1996; SAVELEV \& al., 2004). S. lavandulifolia essential oil inhibits human brain AChE in vitro in human postmortem brain tissue at quite low concentration. The inhibition is more effective when synaptic acetylcholine levels are low as happens in Alzheimer's disease, suggesting that the inhibition is competitive. Furthermore, AChE is more inhibited than butyrylcholinesterase by essential oil. In addition, it interacts with nicotinic and muscarinic receptors (PERRY \& al., 1996) and bovine erythrocyte $\mathrm{AChE}$ in vitro (PERRY \& al., 2000a). And this AChE inhibition in selected brain areas was confirmed in vivo after oral administration of essential oil to young rats. Compared with control group, there was a significant decrease in AChE activity in the striatum but not in the hippocampus at lower dose. At higher dose the decrease is in both places (PERRY \& $a l ., 1996$; PERRY \& al., 2002). 1,8-cineole and $\alpha$ pinene present the most inhibition of the enzyme, against bovine erythrocyte AChE (PERRY \& al., 2000a) and synergistic effects between them (SAVELEV \& al., 2003). However, other main monoterpenoid constituents are responsible for antiChE activity of the whole essential oil as camphor and bornyl acetate with weak activity (PERRY \& al., 2000a) or borneol, $\alpha$ and $\beta$-pinene. Spanish sage essential oil may be relevant in the treatment of Alzheimer's disease (ABASCAL \& YARNELL, 2004a). The neuronal systems affected present a cholinergic system where essential oil and its constituents demonstrated dose dependent inhibition of erythrocytes human bovine AChE in vitro. Specific monoterpenes, such as $\alpha$-pinene, the most potent inhibitors tested, followed by 1,8 cineole and camphor after as weaker inhibitor, are responsible for the in vitro effect. All of them present uncompetitive reversible inhibitor dose-dependent activity. No single component is particularly potent, suggesting a synergistic relationship. Then, monoterpenes were less active than the alkaloidal AChE inhibitors such as physostigmine (PERRY \& al., 2000a).

\section{CENTRAL NERVOUS SYSTEM DEPRESSANT ACTIVITY}

This action has been shown by monoterpenoids linalool and terpineol in vivo through glutamatergic systems. Salvia species has been frequently used as anxiolytic and sedative (PERRY \& al., 2003).

\section{ANTIFUNGAL ACTIVITY}

In a study against pathogenic Candida albicans, S. lavandulifolia possess the strongest antifungal activity compared with other species of 
Salvia. Usually the chemical composition of the oil has influential properties; probably its main components $(1,8$-cineole and camphor) have antifungal activity (JIROVETZ \& al., 2007).

\section{ANTIMICROBIAL ACTIVITY}

Antimicrobial activity has long been recognized. In vitro essential oil of S. lavandulifolia is used for the control of growth and survival of pathogenic microorganisms by the determination of MIC and $\mathrm{MBC}$, which inhibit the growth of Listeria monocytogenes (RoTA \& al., 2004). There has been observed synergism between carvacrol and $\mathrm{p}$ cymene, its precursor, and between cinnamaldehyde and eugenol. And also it has been observed synergism between the components of essential oil and methods of mild preservation. There is some evidence that minor components have an important role in this activity, possibly by producing a synergistic effect between other components. Generally, essential oils produced from plants harvested during or immediately after flowering present the strongest activity (BURT, 2004). Phenolic components are the most active and usually act as membrane permeabilisers. Gram-positive organism is generally more sensitive to essential oil than gramnegative. Antimicrobial activity of essential oils has been mainly attributed to the presence of 1,8 cineole, $\beta$-thujone, camphor, borneol and $\mathrm{p}$ cymene (PierozAn \& al., 2009).

\section{СутотохіC ACTIVITY}

In some studies, the cytotoxic activities of oil were tested on cultures of different human tumor cell compared to doxorubicin and anticancer agent. The tumor cells used were from human promyelocytic leukemia, human chronic myelogenous leukemia, human breast adenocarcinoma and human ovarian adenocarcinoma. S. lavandulifolia essential oil were less active than the control antineoplasic doxorubicin against tumor cells, however unless weak cytotoxic activity of oil is present (FORAY \& al., 1999). The cytotoxic capacity of the essential oils is based on a prooxidant activity by damage the cell wall and membrane and lysis cell finally or also by reducing local tumor size or its proliferation by apoptotic. For example, geraniol inhibits colon cancer cell proliferation by membrane depolarisation and ionic canals of signaling pathways (BAKKALI \& al., 2008).

\section{BIOACTIVITY OF ESSENTIAL OIL'S COMPONENTS}

Essential oils and their constituents have been used since ancient times to prevent and treat many diseases because of their pharmaceutical properties (EDRIS, 2007). They have been used as antimicrobial, fungicidal, antiparasitical, medicinal and cosmetic applications. Nowadays, they are frequently used in pharmaceutical, cosmetic, agricultural and food industries (BAKKALI \& al., 2008). Essential oils are complex mixtures of compounds with beneficial or adverse effects. Some studies show that the interaction between whole essential oil have a greater activity than some mixed components, which suggest that even minor components are critical to the activity. Synergism effect is observed when the effect of the combined substances is greater than the individual effects. In contrast, antagonism is observed when the effect of one or both components is less when they are applied together than individually (BURT, 2004). S. lavandulifolia essential oil activity is attributed to the behavior of several components simultaneously, not individually (CRESPO \& al., 1986). Volatile constituents of the essential oil likely cross the blood-brain barrier for their lipophilicity and small molecular size (SAVELEV \& al., 2004). S. lavandulifolia essential oil produces some significant effects on cognition. S. lavandulifolia essential oil inhibit acethylcholinesterase enzyme and its monoterpenoids alone produce this effect with different potency (SAVELEV \& al., 2003; PERRY \& al., 2000a; PERRY \& al., 2002). These activities may be particularly important in degeneration associated with age, such as dementia. Therefore effects of S. lavandulifolia essential oil are really relevant to potential treatment of central nervous system disorders such as Alzheimer's disease. Many secondary metabolites from plants are used in phytotherapy, cosmetics or aromatherapy. The components activity of essential oil of S. lavandulifolia identified by different studies is summarized in Table 3. 


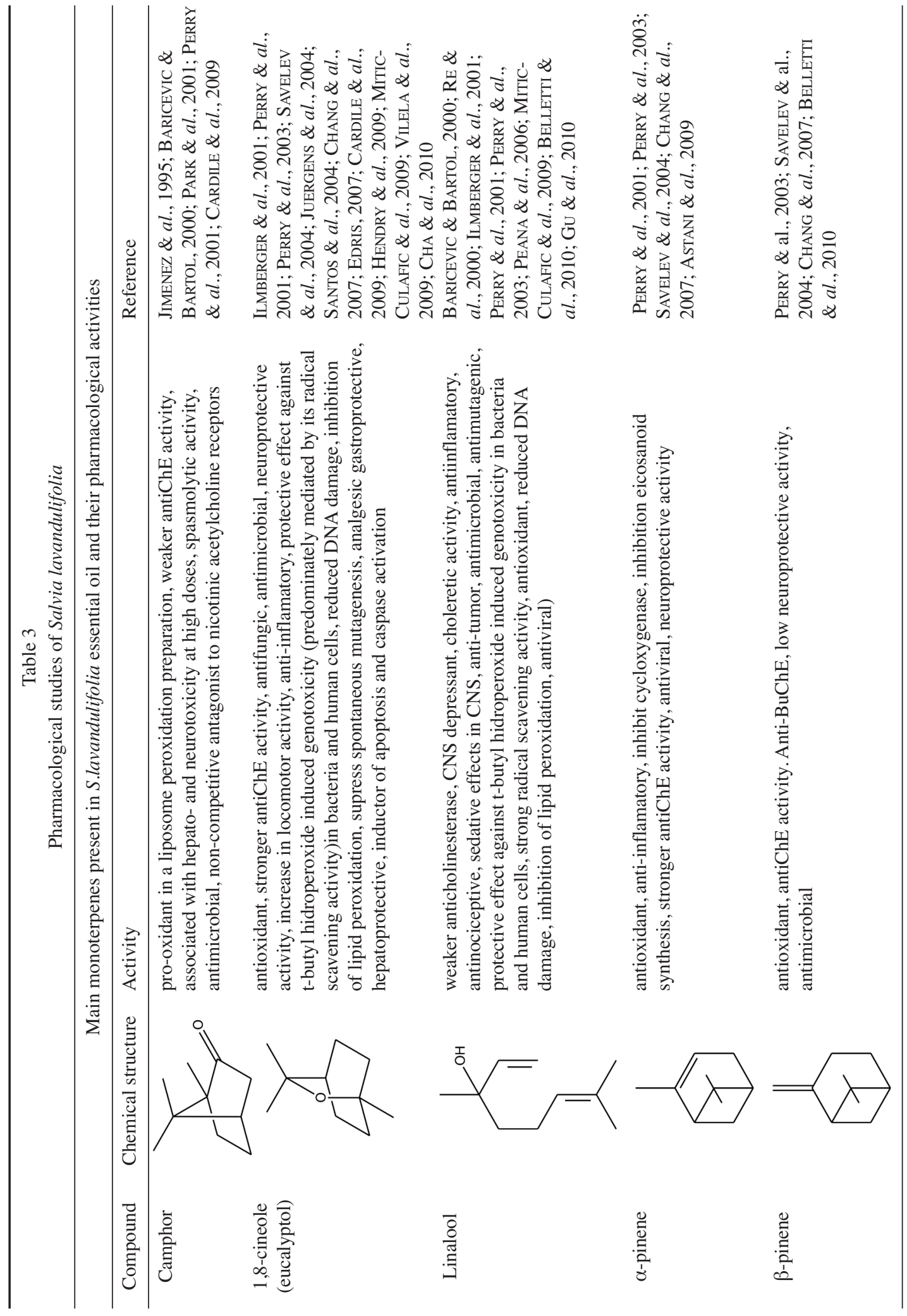


María Porres-Martínez \& al.

Pharmacological activity of Salvia lavandulifolia

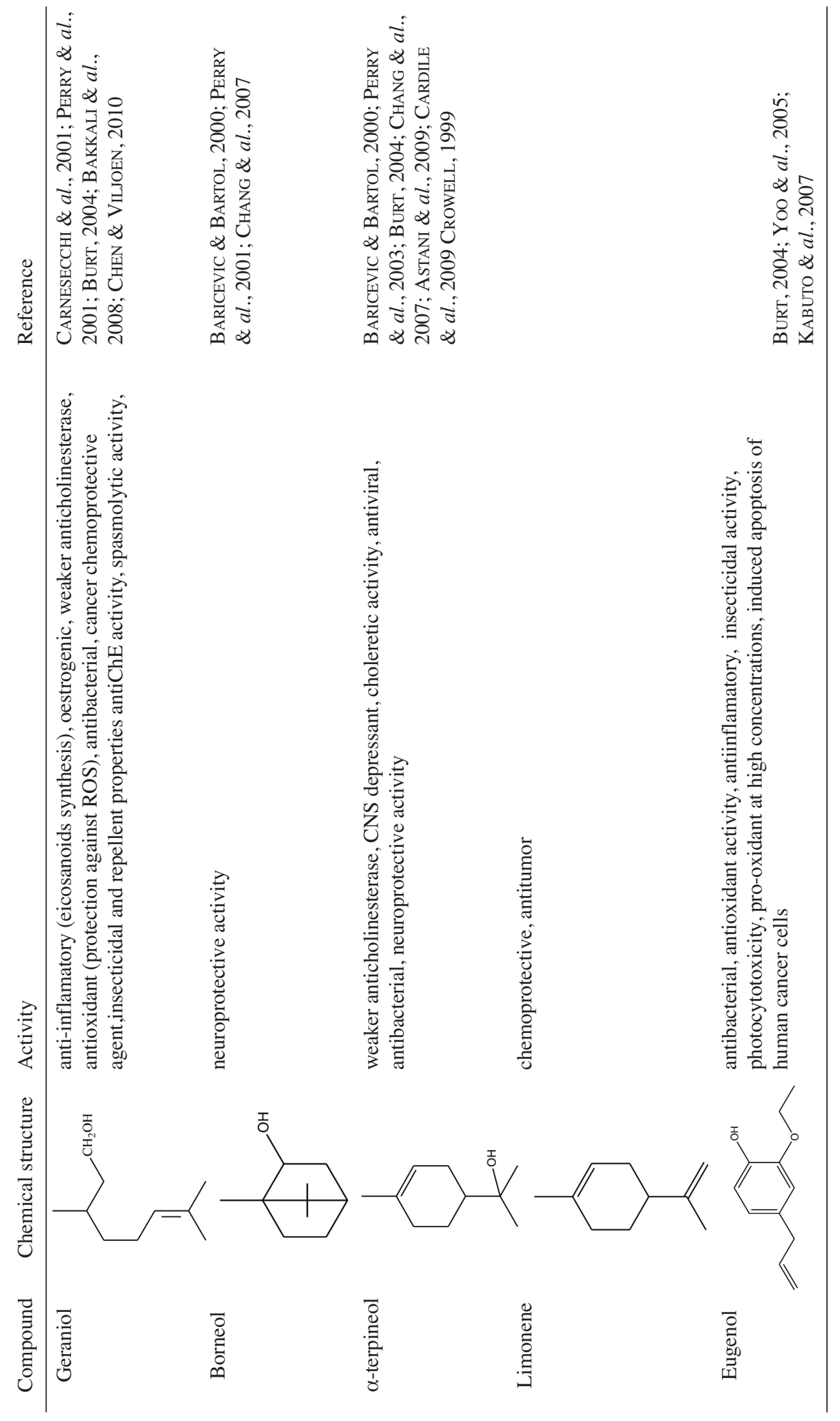




\section{SAFETY: TOXICOLOGY AND SIDE EFFECTS}

Only trace of the convulsant thujone, (a terpenoid ketone), could be detected at any time in vegetative cycle of Spanish sage. Ph. $<0.5 \%$ (BRUNETON, 2001; BARICEVIC \& BARTOL, 2000). S. lavandulifolia is closely related to $S$. officinalis sharing similar composition, with the exception of potentially toxic thujone. Its concentration (1.30-22.82\% $\alpha$-thujone and $0.01-4.32 \% \beta$-thujone) makes the difference with $S$. officinalis, where it is higher (1.20$45.80 \% \alpha$-thujone and 1.02-40.10 $\beta$-thujone). Thujone in large doses is toxic (Tildesley \& al., 2003; abascal \& al., 2004b). For this reason $S$. lavandulifolia is more suitable species to investigate comparison with $S$. officinalis (Giannouli \& Kintzios, 2000; Perry \& al., 2000a). The $\alpha$-thujone, the known GABA-a receptor antagonist monoterpenoid (JOHNSTON \& BeART, 2004; KenNEDy \& al., 2011), present genotoxicity, reproductive toxicity, chronic toxicity, neurotoxicity and carcinogenicity testing in rats and mice (HöLD \& al., 2001). Most of the commercial samples present the terpenoid sabinyl acetate $(0.1-24 \%$ according to the subspecies, the chemotype and their origin) (AFNOR norm: NFT 75-212). This shows potential teratogenicity activity and dose-dependent abortifacient effect; while it does not present fetotoxicity in mice. For these reasons its use should be avoided in pregnant women (PAges \& al., 1992; Fournier \& al., 1993). The most important proportions of sabinyl acetate are from $S$. lavandulifolia subsp. vellerea (MARCos \& al., 1988). There are potential adverse effects associated with the overdose of essential oils. High percentage of ketones in essential oils (camphor or thujone) are contraindicate in patients with epilepsy for the epileptiform activity of these compounds. Camphor poisoning, produces gastrointestinal and CNS irritation after toxic ingestion and it is associated with hepatotoxicity and toxicity in kidney (Millet \& al., 1981; SCHNiTZler \& al., 2008). For these reasons, Salvia are not considered poisonous (unless at very high dosage) (PERRY \& al., 1998).

\section{CONCLUSIONS AND FUTURE APPLICATIONS}

Since immemorial times, several plants have been used not only in diet but also for the therapy of diseases. Although Salvia species are well known to be used in folk medicine, the experimental studies to support their use are largely lacking. Many of these species possess activity on the central nervous system, traditionally used to support memory. Sage can be used in the treatment of Alzheimer's disease symptoms (PERRY \& al., 2003). The inhibition of AChE activity by bycyclic monoterpenoids ( $\alpha$ - and $\beta$-pinene, camphor and borneol) was studied by the colorimetric method of ElLMAN (1961). In the last years, the essential oils of plants have been great interest as a source of natural products, and an alternative treatment of some diseases, due to the presence of secondary metabolites. Essential oils of Lamiaceae family present high biological activities as antimicrobial, antibacterial, antiinflamatory and antioxidant. They have been recognized by its curative, nutritional and cosmetic properties. This is due to its secondary metabolites. Currently, they are widely used in aromatheraphy; however they cannot be applied to human skin in a pure form, in food, cosmetic and pharmaceutical industries. Several studies have shown that Salvia lavandulifolia present properties to attenuate the cognitive decline in natural aging and dementia. The improvement mood and cognition-enhancing effects of sage also exhibit anti-oxidant, antiinflammatory and oestrogenic properties (PERRY \& $a l ., 2003$ ), relevant to brain function (KENNEDY \& SCHOLEY, 2006). These results demonstrate that Salvia lavandulifolia, its essential oil and some constituents have properties relevant to the treatment of neurodegenerative disorders due to its reported memory-enhancing properties. S. lavandulifolia has shown to possess not only properties to the treatment of cognitive decline associated with Alzheimer's disease, but also in the general cognitive enhancement of healthy people. Salvia is well tolerated and without side effects of some treatment. S. lavandulifolia essential oil was a potent inhibitor of human cholinesterase (AChE) but BuChE was weakly inhibited. This cholines- 
terase inhibition may explain its traditional use for ailing memory, for example it is relevant to the treatment of Alzheimer's disease (SAVELEV \& $a l ., 2004)$. Although evidence indicates that $S$. lavandulifolia may be appropriate to the treatment of neurodegenerative disorders as Alzheimer's disease, further investigation in vitro and in vivo are necessary to determinate structure, pharmacological activity relationship, the interaction of their compounds, -since monoterpenoids have demonstrated to inhibit enzymes of the cytochrome P-450 2B subfamily-, and to exploring the potential clinical value of $S$. lavandulifolia. Salvia is potentially a novel therapeutic treatment for neurodegenerative disorders as Alzheimer's disease. Studies on identification of active S. lavandulifolia constituents are important in the search for new therapeutic compounds. The activity of essential oil can be the result of complex interactions between its different constituents, which may produce even at low concentrations additive, synergistic or antagonistic effects of some compounds in the mixture of oil composition. Mixture - might present a very active compound which should be determined and purified. Subsequently, the effects of the oil would be better than isolated monoterpenes (BAKKALI \& al., 2008). These finding reveal that the monoterpenoids may present synergistic and antagonistic complex interactions between the components to produce different activities, such as inhibitory activity of enzyme acetilcholinesterase. The inhibitory activity of essential oil results from a complex interaction between its components, that present synergic and antagonic activities between the monoterpenoids. For example, minor synergy between 1,8 cineole and $\alpha$-pinene, and 1,8 cineole and caryophyllene epoxide, and antagonism between 1,8-cineole and camphor. Then, high concentration of 1,8-cineole and low camphor contents in essential oil may increase its anticholinesterase activity. The 1,8-cineole is a selective inhibitor for AChE but not for butyrylChE (SAVELEV \& al., 2003). It was reported positive effects on three mood dimensions: alertness, contentedness and calmness in a dosedependent manner, modulating mood and cognition evaluated by Cognitive Drug Research test. Specifically, following oral administration of essential oil the immediate and delayed verbal memory was improved.

In the light of these findings, further research is required to determinate the bioactive constituents of plants and elucidate their molecular mechanism of action to therapeutic application. Because, due their low cost and commercial availability might be interesting candidates to the development of dietary or pharmaceutical products.

\section{REFERENCES}

Abascal, K. \& Yarnell, E. -2004- Alzheimer's Disease: part 1 (Biology and Botanicals) - Alternat. Compl. Ther. 10: 18-21.

Abascal, K. \& Yarnell, E. -2004-Alzheimer's Disease: part 2 (a Botanical treatment plan) - Alternat. Compl. Ther. 10: 67-72.

Adams, M., Gmunder, F. \& Hamburger, M. -2007-Plants traditionally used in age related brain disorders-A survey of ethnobotanical literature - J. Ethnopharmacol. 113: 363-381

AENOR - 2001 - Aceites esenciales. Aceite esencial de Salvia de España (Salvia lavandulifolia Vahl.). Norma Española UNE 84310 - Spanish Standardization Association Madrid.

Akhondzadeh, S., Noroozian, M., Mohammadi, M., Ohadinia, S., Jamshidi, A.H. \& Khani, M. - 2003 - Salvia officinalis extract in the treatment of patients with mild to moderate Alzheimer's disease: a double blind, randomi- zed and placebo-controlled trial - J. Clin. Pharm. Ther. 28: 53-59.

Amiri, H. - 2007- Quantitative and qualitative changes of essential oil of Salvia bracteata Bank et Sol. in different growth stages - DARU 15(2): 79-82.

Aruoma, O.I. - 1996- Assessment of potential prooxidant and antioxidant actions - J. Am. Chem. Soc. -73: 1617-1625.

Astani, A., Reichling, J. \& Schnitzler, P. -2009- Comparative study on the antiviral activity of selected monoterpenes derived from essential oils - Phytother Res. 24(5): 673-9.

Bakkali, F.,Averbeck, S.,Averbeck, D. \& Idaomar, M. - 2008Biological effects of essential oils- A review - Food Chem. Toxicol. 46: 446-475.

Baricevic, D. \& Bartol, T. - 2000 - The biological/pharmacological activity of the Salvia genus. Sage: the genus Salvia. Medicinal and Aromatic Plants - In: Kintzios, 
S.E. (Ed). Harwood Academic Publishers. 14(11). Pp. 143-184. Amsterdam.

Belletti, N., Kamdem, S.S., Tabanelli, G., Lanciotti, R. \& Gardini, F. - 2010 - Modeling of combined effects of citral, linalool and $\beta$-pinene used against Saccharomyces cerevisiae in citru-based beverages subjected to a mild heat treatment - Int. J. Food Microbiol. 136: 283-289.

Blumenthal, M., Goldberg, A. \& Brinckmann, J. -2000Herbal Medicine Expanded Commision E Monographs - American Botanical Council. Pp. 330-334.

Bruneton, J. - 2001 - Farmacognosia. Fitoquímica. Plantas Medicinales. (2nd Ed). ACRIBIA. Pp. 477-570. Zaragoza.

Burt, S. -2004- Essential oils: their antibacterial properties and potential applications in foods- a review - Int. J. Food Microbiol. 94: 223-253.

Cañigueral, S., Iglesias, J., Hamburger, M. \& Hostettmann, K. - 1989- Phenolic constituents of Salvia lavandulifolia ssp. lavandulifolia - Planta Med. 55:92.

Cardile, V., Russo, A., Formisano, C., Rigano, D., Senatore, F., Arnold, N.A. \& Piozzi, F. -2009- Essential oils of Salvia bracteata and Salvia rubifolia from Lebanon: chemical composition, antimicrobial activity and inhibitory effect on human melanoma cells - J. Ethnopharmacol. 126: $265-272$.

Carnesecchi, S., Schneider, Y., Ceraline, J., Duranton, B., Gosse, F., Seiler, N. \& Raul, F. -2001- Geraniol, a component of plant essential oils, inhibits growth and polyamine biosynthesis in human colon cancer cells J. Pharmacol. Exp. Ther. 298: 197-200.

Cha, J.D., Kim, Y.H. \& Kim, J.Y. -2010 - Essential oil and 1,8-cineole from Artemisia lavandulaefolia induces apoptosis in KB cells via mitochondrial stress and caspase activation - Food Sci. Biotechnol. 19(1): 185-191.

Chang, H., Kim, H.J. \& Chun, H.S. -2007- Quantitative structure-activity relationship (QSAR) for neuroprotective activity of terpenoids - Life Sci. 80: 835-841.

Chen, W. \& Viljoen, A.M. -2010 - Geraniol- A review of a commercially important fragrance material $-\mathrm{S}$. African J. Bot.76: 643-651.

Clebsch, B. - 2003 - The new book of Salvias. Sages for every garden. Timber Press. 170-171 pp.

Crespo, M.E., Jimenez, C. \& Zarzuelo, A. - 1986 - The essential oil of Salvia lavandulifolia subspecies oxydon. A study of its vegetative cycle - Planta Med. 52: 367-369.

Crowell, P. - 1999- Prevention and therapy of cancer by dietary monoterpenes. Symposium on phytochemicals: biochemistry and physiology - J. Nutr. 115S-778S.

Donaire, F., Fernández-López, C. \& González-Martín, A. - 1992 - Labiadas de la provincia de Jaén II - Blancoana 9: 79-87.

Dweck, A.C. - 2000 - The folklore and cosmetic use of various Salvia species. Medicinal and Aromatic Plants - In: Kintzios, SE (Ed). Sage: the Genus Salvia. 14(1). Pp. 1-25.

Edris, A.E. -2007- Pharmaceutical and therapeutic potentials of essential oils and their individual volatile constituents: a review - Phytother. Res. 21(4): 308-23.
Ellman, G.L., Coutney, K.D., Valentino, C., Zarzuelo, A. \& Feathertone, R.M. - 1961 - A new and rapid colorimetric determination of acetylcholinesterase activity Biochem. Pharmacol. 7: 88-95.

Escudero, J., Perez, L., Rabanal, M.R. \& Valverde, S. 1983 - Diterpenoids from Salvia oxydodon and Salvia lavandulifolia - Phytochem. 22(2): 585-587.

Anon. -2004- European Pharmacopoeia, 5th Ed. Council of Europe, Strasbourg.

Fernández González, F., Loidi, J. \& Molina, A. —1986Contribución al estudio de los matorrales aragoneses: los Salviares riojano-estelleses - An. Jard. Bot. 42(2):451459. Madrid.

Figuerola, R. - 1987- Datos nomenclaturales sobre Salvia lavandulifolia Vahl y Salvia blancoana Webb \& Heldr. (Labiatae). Notas breves - An. Jard. Bot. 44(1): 173174. Madrid.

Font Quer, P. - 1999 - Plantas Medicinales, el Dioscórides Renovado - Ed. Labor, Barcelona. 678 pp.

Foray, L., Bertrand, C., Pinguet, F., Soulier, M., Astre, C., Marion, C., Pelissier, Y. \& Bessiere, J.M. -1999- In vitro cytotoxic activity of three essential oils from Salvia species - J. Essent. Oil Res. 11: 522-526.

Fournier, G., Pages, N. \& Cosperec, I. -1993 - Contribution to the study of Salvia lavandulaefolia essential oil: potential toxicity attributable to the sabinyl acetate Planta Med. 59: 96-97.

Franz, C.M. - 2010 - Essential oil research: past, present and future - Flavour. Frag. J. 25: 112-113.

Gali-Muhtasib, H., Hilanb, C. \& Khater, C. -2000 - Traditional uses of Salvia libanotica (East Mediterranean sage) and the effects of its essential oils - J. Ethnopharmacol. 71(3): 513-520.

Giannouli, A.L. \& Kintzios, S.E. - 2000- Essential oils of Salvia spp: examples of intraspecific and seasonal variation - In: Kintzios, S.E. (Ed.). Sage: the Genus Salvia. 14(5): 69-79.

González, J.A., García-Barriuso, M., Ramírez-Rodríguez, R., Bernardos, S. \& Amich, F. -2012- Plants used in folk cosmetics and hygiene in the Arribes del Duero Natural Park (western Spain) - Lazaroa 33: 9-18.

Gu, Y., Ting, Z., Qiu, X., Zhang, X., Gan, X., Fang, Y., Xu, X. \& Xu, R. - 2010 - Linalool preferentially induces robust apoptosis of a variety of leukemia cells via upregulating p53 and cyclin-dependent kinase inhibitors Toxicology 268: 19-24.

Guillén, M.D. \& Ibargoitia, M.L. - 1995- Wild growing Spanish sage as a raw material in the food industry. Study by gas chromatography/mass spectrometry of its essential oil and extracts in several organic solvents Chem. Mikrobiol. Technol. Lebensm. 17(5/6): 129-134.

Guillén, M.D. \& Manzanos, M.J. - 1999- Extractable components of the aerial parts of Salvia lavandulifolia and composition of the liquid smoke flavoring obtained from them - J. Agric. Food Chem. 47: 3016-3027.

Hendry, E.R., Worthington, T., Conway, B.R. \& Lambert, P.A. - 2009- Antimicrobial efficacy of eucalyptus oil 
and 1.8-cineole alone and in combination with chlorhexidine digluconate against microorganisms grown in planktonic and biofilms cultures - J.A.C. 64: 12191225.

Herraiz-Peñalver, D., Usano-Alemany, J., Cuadrado, J., Jordan, M.J., Lax, V., Sotomayor, J.A. \& Palá-Paúl, J. 2010 - Essential oil composition of wild populations of Salvia lavandulifolia Vahl. from Castilla-La Mancha (Spain) - Biochem. Syst. Ecol. 38(6): 1224-1230.

Hervás Serrano, J.L., Peñafiel Trueba, M.S., Fernández Ocaña, A.M. \& Fernández López C. -1997- Labiadas del Alto Guadalquivir hasta 1995 - Blancoana 14: 93103.

Höld, K.M., Sirisoma, N.S. \& Casida, J.E. -2001 - Detoxification of $\alpha$ - and $\beta$-thujones (the active ingredients of Absinthe): site specificity and species differences in cytochrome $\mathrm{P} 450$ oxidation in vitro and in vivo Chem. Res. Toxicol. 14: 589-595.

Houghton, P.J. \& Howes, M.J. - 2005 - Natural products and derivates affecting neurotransmission relevant to Alzheimer's and Parkinson's disease - Neurosignals 14: 6-22.

Houghton, P.J., Ren, Y. \& Howes, M.J. -2006 - Acetylcholinesterase inhibitors from plants and fungi - Nat. Prod. Rep. 23: 181-199.

Houghton, P.J. - 2004- HerbalGram. Activity and Constituents of Sage Relevant to the Potential Treatment of Symptoms of Alzheimer's Disease - Am. Bot. Council 61: 38-53.

Howes, M.J., Perry, N. \& Houghton, P.J. - 2003 - Plants with traditional uses and activities, relevant to the management of Alzheimer's disease and other cognitive disorders - Phytother. Res.17: 1-18.

Ilmberger, J., Heuberger, E., Mahrhofer, C., Dessovic, H., Kowarik, D. \& Buchbauer, G. - 2001 - The influence of essential oils on human attention. I: Alertness Chem. Senses. 26: 239-245.

Imanshahidi, M. \& Hosseinzadeh, H. -2006- The pharmacological effects of Salvia species on the central nervous system - Phytother. Res. 20: 427-237.

Jiménez, I., Jiménez, J., Gámez, M.J., González, M., Sánchez de Medina, F. \& Zarzuelo, A. - 1995 - Effects of Salvia lavandulifolia Vahl. ssp. oxydon extract on pancreatic endocrine tissue in streptozotocin-diabetic rats - Phytother. Res. 9: 536-537.

Jirovetz, L., Wlcek, K., Buchbauer, G., Gochev, V., Girova, T., Stoyanova, A., Schmidt, E. \& Geissler, M. -2007Antifungal activities of essential oils of Salvia lavandulifolia, Salvia officinalis and Salvia sclarea against various pathogenic Candida species - J. Essent. Oil. Bear Pl. 10(5): 430-439.

Johnston, G.A. \& Beart, P.M. - 2004- Flavonoids: some of the wisdom of sage? - Br. J. Pharmacol. 142: 809-810.

Jordan, M.J., Martinez, C., Moñino, M.I., Lax, V., Quilez, M. \& Sotomayor, J.A. - 2009- Chemical characterization of Salvia lavandulifolia subsp. vellerea in southeastern Spain - Acta Hort. 826: 317-321.
Juergens, U.R., Engelen, T., Racké, K., Söber, M., Gillissen, A. \& Vetter, H. - 2004- Inhibitory activity of 1,8-cineol (eucalyptol) on cytokine production in cultured human lymphocytes and monocytes - Pulm. Pharmacol. Ther. 17: 281-287.

Kabuto, H., Tada, M. \& Kohno, M. -2007- Eugenol \{2methoxy-4-(2-propenyl)phenol\} prevents 6-hydroxydopamine-induced dopamine depression and lipid peroxidation inductivity in mouse striatum - Biol. Pharm. Bull. 30(3): 423-427.

Kelen, M. \& Tepe, B. - 2008 - Chemical composition, antioxidant and antimicrobial properties of the essential oils of three Salvia species from Turkish flora - Bioresour. Technol. 99(10): 4096-4104.

Kennedy, D.O. \& Wightman, E.L. - 2011 - Herbal extracts and phytochemicals: plant secondary metabolites and the enhancement of human brain function. American Society for Nutrition - Adv. Nutr. 2: 32-50.

Kennedy, D.O., Dodd, F.L., Robertson, B.C., Okello, E.J., Reay, J.L., Scholey, A.B. \& Haskell, C.F. -2010 - Monoterpenoid extract of sage (Salvia lavandulaefolia) with cholinesterase inhibiting properties improves cognitive performance and mood in healthy adults - J. Psychopharmacol. 1-13.

Kennedy, D.O. \& Scholey, A.B. - 2006- The psychopharmacology of European herbs with cognition-enhancing properties - Curr. Pharm. Des. 12: 4613-4623.

Kennedy, D.O. - 2009- Herbs affecting the central nervous system - Evaluation of herbal medicinal products 14: 187-202.

Lawrence, B.M., Hogg, J.W. \& Terhune, S.J. -1970 - Essential oils and their constituents. III. Some new trace constituents in the essential oil of Salvia lavandulifolia, Vahl - J. Chrom. 50: 59-65.

Lázaro Bello, J.A. - 2011 - Análisis florístico de las escombreras situadas en el centro-norte de la provincia de Valladolid (España) - Lazaroa 32: 117-136.

Loizzo, M.R., Menichini, F., Tundis, R., Bonesi, M., Conforti, F., Nadjafi, F., Statti, G.A. \& Frega, N.G., Menichini, F. - 2009- In vitro biological activity of Salvia leriifolia Benth essential oil relevant to the treatment of Alzheimer's disease - J. Oleo Sci. 58(8): 443-446.

Lu, Y. \& Foo, Y. - 2002 - Polyphenolics of Salvia-a review - Phytochemistry 59: 117-140.

Mantle, D., Pickering, A.T. \& Perry, E.K. -2000- Medicinal plant extracts for the treatment of Dementia. A review of their pharmacology, efficacy and tolerability CNS Drugs 13(3): 201-213.

Marcos Sanz, M.E., García Vallejo, M.C., Muñoz López, F. \& Polo Diez, L.M. - 1988 - The essential oil of Salvia lavandulaefolia Vahl - Dev. Food Sci. 18: 147-160.

Millet, Y., Jouglard, J., Steinmetz, M.D., Tognetti, P., Joanny, P. \& Arditti, J. - 1981 - Toxicity of some essential plant oils. Clinical and experimental study - Clin. Toxicol. 18(12): 1485-1498.

Mitic-Culafic, D., Zegura, B., Nikolic, B., Vukovic-Gacic, B., Knezevic-Vukcevic, J. \& Filipic, M. -2009- Protective 
effect of linalool, myrcene and eucalyptol against t-butyl hydroperoxide induced genotoxicity in bacteria and cultured human cells - Food Chem. Toxicol. 47: 260-266.

Miyazawa, M. \& Yamafuji, C. - 2005- Inhibition of acetylcholinesterase activity by bicyclic monoterpenoids - J. Agric. Food Chem. 53: 1765-1768.

Moss, L., Rouse, M., Wesnes, K.A. \& Moss, M. -2010Differential effects of the aromas of Salvia species on memory and mood - Hum. Psychopharmacol. Clin. Exp. 25: 388-396.

Pages, N., Fournier, G., Velut, V. \& Imbert, C. - 1992Potential teratogenicity in mice of the essential oil of Salvia lavandulaefolia Vahl. Study of a fraction rich in sabinyl acetate - Phytotherapy Res. 6: 80-83.

Palacio, S., Milla, R., Albuixech, J., Pérez-Rontomé, C., Camarero, J.J., Maestro, M. \& Montserrat-Martí, G. 2008 - Seasonal variability of dry matter content and its relationship with shoot growth and nonstructural carbohydrates - New Phytol. 180: 133-142.

Panagiotopoulos, E., Skapeti, M. \& Kapetanos, C. 2000 - Production of secondary metabolites using liquid culture of Salvia plants: up-to-date reports and scale-up potential - In: Kintzios, S.E. (Ed.). Sage: the Genus Salvia. 14(18): 251-262.

Papageorgiou, V., Gardeli, C., Mallouchos, A., Papaioannou, M. \& Komaitis, M. - 2008 - Variation of the chemical prolife and antioxidant behavior of Rosmarinus officinalis L. and Salvia fruticosa Miller grown in Greece - J. Agric. Food Chem. 56: 7254-7264.

Park, T.J., Seo, H.K., Kang, B.J. \& Kim, K.T. - $2001-$ Non-competitive inhibition by camphor of nicotinic acethylcholine receptors - Biochem. Pharmacol. 61: 787-793

Peana,A.T., Marzocco, S., Popolo, A. \& Pinto, A. - 2006(-)-linalool inhibits in vitro NO formation: probable involment in the antinociceptive activity of this monoterpene compound - Life Sci. 78: 719-723.

Peyrat, L.A., Trawinska, M.J. \& Gavilán, R.G. -2012Identification of Medicinal Plants in the Ciudad Universitaria (Madrid): new data from microscopic observations - Lazaroa 33: 199-206.

Perry, E.K., Pickering, A.T., Wang, W.W., Houghton, P.J. \& Perry, N.S. - 1998 - Medicinal plants and Alzheimer's disease: integrating ethnobotanical and contemporary scientific evidence - J.Altern. Compl. Med. 4: 419-428.

Perry, E.K., Pickering, A.T., Wang, W.W., Houghton, P.J., Perry, N.S. - 1999- Medicinal plants and Alzheimer's disease: from ethnobotany to phytotherapy $-\mathrm{J}$. Pharm. Pharmacol. 51: 527-534.

Perry, N.S., Bollen, C., Perry, E.K. \& Ballard, C. - 2003Salvia for dementia theraphy: review of pharmacological activity and pilot tolerability clinical trial - Pharm. Biochem. Behav. 75: 651-659.

Perry, N.S., Court, G., Bidet, N., Court, J. \& Perry, E.K. 1996- European herbs with cholinergic activities: potential in dementia theraphy - Int. J. Ger. Psych. 11: 1063-1069.
Perry, N.S., Houghton, P.J., Jenner, P., Keith, A. \& Perry, E.K. - 2002- Salvia lavandulaefolia essential oil inhibits cholinesterase in vivo - Phytomed. 9: 48-51.

Perry, N.S., Houghton, P.J., Theobald, A., Jenner, P. \& Perry, E.K. - 2000 - In-vitro inhibition of human erythrocyte acetylcholinesterase by Salvia lavandulaefolia essential oil and constituent terpenes - J. Pharm. Pharmacol. 52: 895-902.

Perry, N.S. \& Perry, E.K. - 2006- Aromatheraphy in the management of psychiatric disorders - CNS Drugs 20(4): 257-280.

Perry, N.S., Houghton, P.J., Sampson, J., Theobald, A., Hart, S., Lis-Balchin, M., Hoult, R., Evans, P., Jenner, P., Milligan, S. \& Perry, E.K. - 2001 - In-vitro activity of S.lavandulaefolia (Spanish sage) relevant to treatment of Alzheimer's disease - J. Pharm. Pharmacol. 53: 1347-1356.

Perry, N.S., Howes, M.J., Houghton, P.J. \& Perry, E.K. 2000 - Why sage may be a wise remedy: effects of Salvia on the nervous system. Medicinal and Aromatic Plants - In: Kintzios, S.E. (Ed.). Sage: the Genus Salvia. 14(14): 207-223.

Pierozan, M.K., Pauletti, G.F., Rota, L., Santos, A.C., Lerin, L.A., Di Luccio, M., Mossi, A.J., Atti-Serafini, L., Cansian, R.L. \& Oliveira, J.V. -2009- Chemical characterization and antimicrobial activity of essential oils of Salvia L. species - Ci. Tec. Alim. 29(4): 764-770.

Ramos, A.A., Azqueta, A., Pereira-Wilson, C., Collins, A.R. -2010 - Polyphenolic compounds from Salvia species protect cellular DNA from oxidation and stimulate DNA repair in cultured human cells - J. Agric. Food Chem. 58:.7465-7471.

Re, L., Barocci, S., Sonnino, S., Mencarelli, A., Vivani, C., Paolucci, G., Scarpantonio, A., Rinaldi, L. \& Mosca, E. -2000 - Linalool modifies the nicotinic receptor-ion cannel kinetics at the mouse neuromuscular function Pharm. Res. 42(2): 177-181.

Rosua, J.L. \& Blanca, G. - 1990- Acerca de la distribución de la sección Salvia (genero Salvia 1., Lamiaceae) en la región mediterránea occidental y sus relaciones de vicarianza con el este del mediterráneo - Lagascalia 15(2): 137-143.

Rosua, J.L. \& Blanca, G. - 1985- Notas cariosistemáticas de la sección Salvia del género Salvia L. (Lamiaceae) An. Jard. Bot. 42(1): 101-112.

Rosua, J.L. \& Blanca, G. - 1986- Revisión del género Salvia L. (lamiaceae) en el mediterráneo occidental: la sección Salvia - Acta Bot. Malacitana 11: 227-272

Rota, C., Carramiñana, J., Burillo, J. \& Herrera, A. 2004- In vitro antimicrobial activity of essential oils from aromatic plants against selected food borne pathogens - J. Food Prot. 67(6): 1252-1256.

Sáez, L. -2010 - Salvia L. Vol. XII.: Verbenaceae-Labiatae-Callitrichaceae - In: Morales, R., Quintanar, A., Cabezas, F., Pujadas, A.J., Cirujano, S. (Eds.). Flora iberica. Pp. 298-326. R. Jard. Bot. Madrid (CSIC), Madrid.

Salhi, S., Fadli, M., Zidane, L. \& Douira, A. -2010 - Etu- 
des floristique et ethnobotanique des plantes médicinales de la ville de Kénitra (Maroc) - Lazaroa 31: 133-146.

Santos, F.A., Silva, R.M., Campos, A.R., de Araujo, R.P., Lima Junior, R.C. \& Rao, V.S. -2004- 1,8-cineole (eucalyptol), a monoterpene oxide attenuates the colonic damage in rats on acute TNBS-colitis - Food Chem. Toxicol. 42: 579-584.

Savelev, S., Okello, E. \& Perry, E.K. - 2004- Butyryl- and acetyl-cholinesterase inhibitory activities in the essential oils of Salvia species and their constituents - Phytotherapy Res. 18: 315-324.

Savelev, S., Okello, E., Perry, N.S., Wilkins, R.M. \& Perry, E.K. - 2003-S ynergistic and antagonistic interactions of anticholinesterase terpenoid in Salvia lavandulaefolia essential oil - Pharmacol. Biochem. Behav. 75: 661-668.

Schnitzler, P., Wiesenhofer, K. \& Reichling, J. -2008Comparative study on the cytotoxicity of different Myrtaceae essential oils on cultures Vero and RC-37 cells - Pharmazie 63: 830-835.

Scholey, A.B., Tildesley, N.T., Ballard, C.G., Wesnes, K.A., Tasker, A., Perry, E.K. \& Kennedy, D.O. -2008- An extract of Salvia (sage) with anticholinesterase properties improves memory and attention in healthy older volunteers - Psychopharmacol. 198: 127-139.

Solanas, J.L. \& Crespo, M.B. -1998 - Posición sintaxonómica de los salviares setabenses - Lazaroa 19: 119-129.

Tambe, Y., Tsujiuchi, H., Honda, G., Ikeshiro, Y. \& Tanaka, S. $-1996-$ Gastric cytoprotection of the non-steroidal anti-inflammatory sesquiterpene, $\beta$-caryophyllene Planta Med. 62: 469-470.

Thackeray, F.L., Haskell, C.F. \& Kennedy, D.O. - 2010Sensitivity of a range of cognitive and mood measures to the psychoactive effects of an essential oil of Salvia lavandulaefolia - Appetite 55: 173.

Tildesley, N.T., Kennedy, D.O., Perry, E.K., Ballard, C., Savelev, S., Wesnes, K.A. \& Scholey, A.B. -2003- Salvia lavandulaefolia (Spanish Sage) enhances memory in healthy young volunteers - Pharmacol. Biochem. Behav. 75: 669-674.

Tildesley, N.T., Kennedy, D.O., Perry, E.K., Ballard, C., Wesnes, K.A. \& Scholey, A.B. - 2005- Positive modulation of mood and cognitive performance following administration of acute doses of Salvia lavandulaefolia essential oil to healthy young volunteers - Physiol. Behav. 83: 699-709.

Topcu, G. - 2006- Bioactive triterpenoids from Salvia species - J. Nat. Prod. 69(3): 482-487.

Hedge, I.C. - 1972 - Salvia - In: Tutin \& al.(Eds.). Flora Europaea, vol 3. Pp. 189. Cambridge Univ. Press, Cambridge.

Ulubelen, A. - 2000 - Terpenoids in the genus Salvia. Chemical constituents - In: Kintzios, S.E. (Ed.). Sage: the Genus Salvia. 14(4): 55-68.
Valdes-Bermejo, E. \& López, G. - 1977- Aportaciones a la flora española - An. Inst. Bot. Cavanilles 34(1): 157173.

Vernin, G. \& Metzger, J. - 1986- Analysis of Sage oils by CG-MS data bank- Salvia officinalis L. and Salvia lavandulaefolia Vahl. - Perfumer \& Flavorist 11: 79-84.

Vilela, G.R., Almeida, G.S., D’Arce, M.A., Moraes, M.H., Brito, J.O., Silva, M.F., Silva, S.C., Piedade, S.M., Calori-Domingues, M.A. \& Gloria, E.M. -2009- Activity of essential oil and its major compound, 1,8-cineole, from Eucalyptus globulus Labill., against the storage fungi Aspergillus flavus Link and Aspergillus parasiticus Speare - J. Stored. Prod. Res. 45: 108-111.

Wake, G., Court, J., Pickering. A., Lewis, R., Wilkins, R. \& Perry, E. - 2000- CNS acetylcholine receptor activity in European medicinal plants traditionally used to improve failing memory - J. Ethnopharmacol. 69: 105114.

Walker, J.B., Sytsma, K.J., Treutlein, J. \& Wink, M. 2004- Salvia (Lamiaceae) is not monophyletic: implications for the systematic, radiation, and ecological specializations of Salvia and Tribe Mentheae - Amer. J. Bot. 91(7): 1115-1125.

Wang, G., Tang, W. \& Bidigare, R.R. - 2005- Terpenoids as therapeutic drugs and pharmaceutical agents. Natural Products: Drug discovery and therapeutic medicine. Edited Zhang, L. \& Demain, A.L. - Humana Press. 9:197227.

Yoo, C.B., Han, K.T., Cho, K.S., Ha, J., Park, H.J., Nam, J.H., Kil, U.H. \& Lee, K.T. - 2005- Eugenol isolated from the essential oil of Eugenia caryophyllata induces a reactive oxygen species-mediated apoptosis in HL-60 human promyelocytic leukemia cells - Cancer letters. 225: 41-52.

Zarzuelo, A., Gamez, J.M., Utrilla, P., Jiménez, J. \& Jiménez, I. - 1995 - Luteolin 5-rutinoside from Salvia lavandulifolia ssp. oxyodon - Phytochemistry 40(4): 1321-1322.

Zarzuelo, A., Risco, S., Gámez, M.J., Jiménez, J., Cámara, M. \& Martínez, M.A. - 1991-Hypoglycemic action of Salvia lavandulifolia Vahl. ssp. oxydon: a contribution to studies on the mechanism of action - Life Sci. 47: 909-915.

Zrira, S., Menut, C., Bessiere, J.M., Elamrani, A. \& Benjilali, B. - 2004- A study of the essential oil of Salvia lavandulifolia Vahl from Morocco - J. Essent. Oil- Bearing plants. 7(3): 232-238.

Zupko, I., Hohmann, J., Redei, D., Falkay, G., Janicsak, G. \& Mathe, I. -2001 - Antioxidant activity of leaves of Salvia species in enzyme-dependent and enzyme-independent systems of lipid peroxidation and their phenolic constituents - Planta Med. 67: 366-368. 